Article

\title{
The Environmental Impact of Consumption Lifestyles: Ethically Minded Consumption vs. Tightwads
}

\author{
Laurie Touchette * and Marcelo Vinhal Nepomuceno * \\ HEC Montréal, 3000 Chemin de la Côte-Sainte-Catherine, Montréal, QC H3T 2A7, Canada \\ * Correspondence: laurie.touchette@hec.ca (L.T.); marcelo.nepomuceno@hec.ca (M.V.N.)
}

Received: 20 October 2020; Accepted: 23 November 2020; Published: 28 November 2020

\begin{abstract}
This study investigates the environmental impact of anti-consumption lifestyles and compares it to environmental concern and ethically minded consumption. Environmental impact was measured in a sample of 357 individuals with a carbon footprint calculator capturing all greenhouse gases released by an individual's activities. Three types of anti-consumption lifestyles were considered: frugality, voluntary simplicity, and tightwadism. Results suggest that tightwadism is negatively associated with environmental impact. This negative association is stronger when participants are knowledgeable about the emissions impact of their behaviors. These findings suggest that tightwadism can lead to positive outcomes to achieve sustainability. Surprisingly, frugality and voluntary simplicity, as well as environmental concern, are not significantly associated with environmental impact, whereas ethically minded consumption correlates positively with the latter. This study demonstrates that increasing consumers' environmental and ethical concerns alone might not be an effective way to lead them towards a more sustainable lifestyle. Such findings have important implications for sustainability and public policy makers.
\end{abstract}

Keywords: anti-consumption lifestyle; sustainability; environmental impact; tightwadism; voluntary simplicity; frugality; environmental concern; ethically minded consumption

\section{Introduction}

The environmental consequences of human activity have earned the interest of academic research since the 1960s [1]. To find solutions to environmental issues, the key role of consumption in driving environmental impact has long been recognised. To this end, authors have examined the psychological processes and motivations behind individuals' environmentally friendly behaviors [2-4]. However, given today's significant environmental challenges such as climate change [5], policies that seek to promote pro-environmental behaviors (e.g., to encourage incremental consumption shifts from regular products to "greener" ones) may not be a sufficient solution in favour of sustainability [1]. Some authors question the environmental reform strategy largely based on promoting green and ethical consumption behaviors, as it will be offset by substantial growth in global consumption [6,7]. They suggest that more effective alternatives to environmental degradation in industrialized nations lie in changing the dominant lifestyles and consumption patterns, which are considered unsustainable. More specifically, these scholars discuss the need to limit consumption for sustainable development purposes [7-11]. In particular, research has focused on understanding how to reduce meat consumption [12-14], energy consumption [15], and car usage and purchase [16-18], as these have strong impact on the environment.

This paper builds on previous literature and stems from the intersection between the fields of consumer behavior and sustainability. Past research suggests that the adoption of anti-consumption lifestyles might contribute to achieving sustainability goals [1,2,19-21]. Anti-consumption urges consumers to buy less products [2], resulting in a voluntary reduction in the acquisition, use, 
and disposal of commoditized goods and services [22]. Following this definition, individuals who adopt anti-consumption lifestyles are motivated to minimize their consumption levels [23], which should lower their negative impact on the environment [20]. This occurs because when consumers systematically resist consumption as an integral part of their lifestyle, fewer resources are requested, and less impact is generated on the environment [24]. However, while the emerging topic of anti-consumption is gaining more attention in the field of consumer behavior, its contribution to sustainability remains largely underexplored. In particular, it is still unclear to what degree anti-consumption lifestyles should reduce one's environmental impact.

To the best of our knowledge, only one study to date has investigated the extent to which the adoption of anti-consumption lifestyles might be associated with lower environmental impact [20]. Its authors found that tightwadism and voluntary simplicity are associated with lower environmental impact than environmental concern and frugality. The present study adds to this existing research and assesses the validity and reproducibility of the findings. It does so by using a more comprehensive measure of environmental impact (i.e., a carbon footprint calculator-Carbon Footprint Ltd., Hampshire, UK 2017). This calculator uses emissions factors considering all greenhouse gases (i.e., $\mathrm{CO}_{2}, \mathrm{~N}_{2} \mathrm{O}$, methane, etc.). Differently from past research, this method considered individual carbon emissions caused by not only food-related consumption, but also energy, transportation, clothing, and numerous other types of products and services (see Tables 1 and 2) allowing for a better representation of all activities undertaken over a year in a highly detailed manner [25].

Table 1. Real score attributed to individual actions according to their potential in reducing $\mathrm{CO}_{2}$ emissions.

\begin{tabular}{|c|c|c|c|}
\hline & Individual Action & $\begin{array}{c}\mathrm{tCO}_{2} / \text { Year } \\
\text { Reduction Potential }\end{array}$ & $\begin{array}{l}\text { Real Score Attributed } \\
\text { (on a Scale of } 1 \text { to } 7 \text { ) }\end{array}$ \\
\hline \multirow{7}{*}{$\begin{array}{l}\text { High impact } \\
\text { actions }\end{array}$} & \multicolumn{3}{|c|}{ More than $0.8 \mathrm{tCO}_{2} /$ year } \\
\hline & Have one fewer child & 58.6 & 7 \\
\hline & Live car free & 2.40 & 6 \\
\hline & $\begin{array}{l}\text { Avoid one transatlantic flight (i.e., have the means } \\
\text { to take a transatlantic flight, but still avoid it) }\end{array}$ & 1.60 & 5 \\
\hline & $\begin{array}{l}\text { Buy green energy (e.g., install solar panels in your } \\
\text { home; buy an Energy Star HVAC system) }\end{array}$ & 1.40 & 5 \\
\hline & $\begin{array}{l}\text { Buy a more efficient car (i.e., a car with at least } 5 \\
\text { miles per gallon above the American average) }\end{array}$ & 1.19 & 4 \\
\hline & $\begin{array}{l}\text { Adopt a plant-based diet (i.e., avoid the intake of } \\
\text { animal products such as meat, milk, eggs, etc.) }\end{array}$ & 0.80 & 4 \\
\hline \multirow{5}{*}{$\begin{array}{l}\text { Moderate } \\
\text { impact } \\
\text { actions }\end{array}$} & \multicolumn{3}{|c|}{ Between 0.2 and $0.8 \mathrm{tCO}_{2} /$ year } \\
\hline & Replace gasoline car by hybrid * & 0.50 & 3 \\
\hline & Wash clothes in cold water & 0.25 & 2 \\
\hline & Recycle & 0.21 & 2 \\
\hline & Hand-dry clothes & 0.21 & 2 \\
\hline \multirow{3}{*}{$\begin{array}{l}\text { Low impact } \\
\text { actions }\end{array}$} & \multicolumn{3}{|c|}{ Less than $0.2 \mathrm{tCO}_{2} /$ year } \\
\hline & Upgrade lightbulbs & 0.10 & 1 \\
\hline & Plant a tree & 0.03 & 1 \\
\hline
\end{tabular}

* Increasing fuel economy might be more effective in terms of $\mathrm{tCO}_{2}$ reduction than switching to a hybrid car (Wynes and Nicholas 2017).

In addition to using a more comprehensive measure of environmental impact, the current research compares frugality, tightwadism, and voluntary simplicity not only to environmental concern, but also to ethically minded consumption. Within the literature, there remains a debate as to the commitment towards ethical purchasing [26]. Since many studies have found a gap between the ethical attitudes consumers say they hold, and their actual purchase behavior [26-31], it was thus important to include ethically minded consumption in this study, as it has yet to prove its positive environmental effects. 
Table 2. Calculation of $\mathrm{CO}_{2}$ emissions per expense category.

\begin{tabular}{|c|c|c|c|}
\hline $\begin{array}{l}\text { Expenditure } \\
\text { Categories }\end{array}$ & Survey Indications & Sub-Categories & $\begin{array}{l}1 \text { Metric ton of } \mathrm{CO}_{2} \mathrm{e} \text { is } \\
\text { Equivalent to: }\end{array}$ \\
\hline $\begin{array}{l}\text { Household } \\
\text { Energy }\end{array}$ & $\begin{array}{l}\text { Participants had to estimate their } \\
\text { household consumption (\$USD) of each } \\
\text { type of energy for the past } 12 \text { months. }\end{array}$ & $\begin{array}{c}\text { Electricity } \\
\text { Natural gas } \\
\text { Heating oil } \\
\text { Coal } \\
\text { Liquefied petroleum gas } \\
\text { (LPG) } \\
\text { Propane } \\
\text { Wood pellets }\end{array}$ & $\begin{array}{c}\$ 2894^{+} \\
\$ 9^{+} \\
\$ 40^{+} \\
\$ 12^{+} \\
\$ 405^{+} \\
\$ 388^{+} \\
\$ 14^{+}\end{array}$ \\
\hline Transportation & $\begin{array}{l}\text { Participants had to provide details about } \\
\text { their travel itineraries by plane over the last } \\
12 \text { months, specifying the city of departure } \\
\text { and destination, the stops made, and class } \\
\text { type they traveled in (e.g., economy, } \\
\text { business, etc.). } \\
\text { Participants had to report the number of } \\
\text { miles driven with their vehicle(s) in the last } \\
12 \text { months, providing accurate information } \\
\text { on the vehicle: manufacturer, model, year } \\
\text { of manufacture, the fuel type, whether it is } \\
\text { manual or automatic, its trim level and fuel } \\
\text { efficiency (miles/gallon). } \\
\text { If participants have a motorcycle, they had } \\
\text { to provide the motorcycle type they own as } \\
\text { well as the number of miles driven. } \\
\text { If the participants used public transport in } \\
\text { the last } 12 \text { months, they had to indicate the } \\
\text { mileage travelled (per week, month, or } \\
\text { year) by commuter train, long-distance } \\
\text { train, local bus, coach bus, subway, tram, } \\
\text { and taxi. }\end{array}$ & $\begin{array}{l}\text { Commuter train } \\
\text { Long-distance train } \\
\text { Local bus } \\
\text { Coach bus } \\
\text { Subway } \\
\text { Tramway } \\
\text { Taxi }\end{array}$ & $\begin{array}{l}\text { Amount of } \$ \text { USD for } 1 \\
\text { metric ton of } \mathrm{CO}_{2} \text { e depends } \\
\text { on the motorcycle type and } \\
\text { fuel efficiency. } \\
14,286 \text { miles } \\
100,000 \text { miles } \\
5882 \text { miles } \\
25,000 \text { miles } \\
20,000 \text { miles } \\
16,667 \text { miles } \\
4167 \text { miles }\end{array}$ \\
\hline $\begin{array}{l}\text { Other } \\
\text { Expenses } \\
\text { (products and } \\
\text { services) }\end{array}$ & $\begin{array}{l}\text { This is a measure of the emissions caused } \\
\text { through the manufacture, delivery and } \\
\text { disposal of products and services } \\
\text { participants buy. Participants had to } \\
\text { estimate the amount spent (per week, } \\
\text { month, or year) on different categories of } \\
\text { goods and services. }\end{array}$ & $\begin{array}{c}\text { Food and beverages * } \\
\text { Pharmaceuticals } \\
\text { Clothing, textiles and shoes } \\
\text { Telephone, mobile/cellphone } \\
\text { call costs } \\
\text { Hotel, restaurants and pubs } \\
\text { Banking and financial sector } \\
\text { (mortgage and interest } \\
\text { payments) } \\
\text { Insurance } \\
\text { Paper-based products (e.g., } \\
\text { books and magazines) } \\
\text { Computer and equipment } \\
\text { Television, radio and phone } \\
\text { (equipment) } \\
\text { Motor vehicles (excluding } \\
\text { fuel costs) } \\
\text { Furniture and other } \\
\text { manufactured good } \\
\text { Education }\end{array}$ & $\begin{array}{l}\$ 1250 \\
\$ 2500 \\
\$ 3750 \\
\$ 2041 \\
\$ 2439\end{array}$ \\
\hline
\end{tabular}

* Indicates $\mathrm{CO}_{2}$ emissions that were divided by the number of people in the household. ${ }^{\dagger}$ For electricity, 1 metric ton of $\mathrm{CO}_{2} \mathrm{e}$ at $0.053 \mathrm{kgCO}_{2} \mathrm{e} / \mathrm{kWh}$ is equal to $18,867 \mathrm{KWh}$. The amount in dollars is $15.34 \mathrm{c} / \mathrm{kWh}$. For natural gas, 1 metric ton of $\mathrm{CO}_{2} \mathrm{e}$ is equal to $5000 \mathrm{KWh}$. The amount in dollars is $0.18 \mathrm{q} / \mathrm{kWh}$. For heating oil 1 metric ton of $\mathrm{CO}_{2} \mathrm{e}$ is equal to 104 US gallons. The amount in dollars is $2.60 / \mathrm{US}$ gallon. For coal, 1 metric ton of $\mathrm{CO}_{2} \mathrm{e}$ is equal to $\$ 33.72 /$ ton . For LPG, 1 metric ton of $\mathrm{CO}_{2} \mathrm{e}$ is equal to 174 US gallons. The amount in dollars is $2.33 / \mathrm{US}$ gallon. For propane, 1 metric ton of $\mathrm{CO}_{2} \mathrm{e}$ is equal to 174 US gallons. The amount in dollars is $2.33 / \mathrm{US}$ gallon. For wood pellets, 1 metric ton of $\mathrm{CO}_{2} \mathrm{e}$ is equal to 0.07 ton of wood. The amount in dollars is $\$ 14 /$ ton. The sources used for the calculations were: https://www.bls.gov; https://www.eia.gov; https://www.globalpetrolprices.com/; https://www.walmart.com.

Finally, this research examines the moderating role of emissions impact knowledge, as we hope to find that it might further reduce one's environmental impact. Past studies have shown that consumers with environmental awareness are more willing to engage in environmentally friendly behaviors [32-34]. We believe that knowledge of high and low emissions actions can further reduce 
anti-consumers' impact on the environment, since they make behavioral choices as part of their lifestyle which have great potential to lower negative emissions.

The anti-consumption lifestyles considered in this study—voluntary simplicity, frugality, and tightwadism-lead to less consumption in general, even though they each operate under different psychological mechanisms [20]. Frugality refers to a resourceful use of material goods and services given the pleasure of saving $[35,36]$. Therefore, a frugal consumer resists the consumption of all products and services because (s)he feels pleasure in saving resources. Voluntary simplicity is adopted by individuals who reduce spending on goods and services to live a simple life and obtain satisfaction by cultivating non-materialistic values $[37,38]$. A simplifier resists consumption by acquiring only the minimum and living very modestly. Tightwadism is characterized by a consumption reduction caused by the pain of spending [36]. Thus, a tightwad minimizes the consumption of products and services because spending money represents a psychologically difficult process. The degree to which individuals identify with these anti-consumption lifestyles might lower their environmental impact [20], since the consumption reduction practices incorporated in their daily lives form an essential part of sustainable living [2].

The contradictory results from studies regarding pro-environmental and ethical concerns cast doubt on their real contribution to environmental protection. Many researchers observe inconsistencies between what consumers say about the importance of ethical consumerism and their actual purchasing behavior, which have been termed the "attitude-behavior gap" [39-43]. Similarly, environmental concern might not be reflected by environmentally friendly consumer behaviors. Although individuals portray themselves as being benevolent in surveys, they continue to give up on their green buying intentions by expressing their preference for unsustainable traditional products, usually because of economic motives [27]. Therefore, in practice, environmentally friendly consumer behavior is significantly lower than expected for environmental concern [28]. Hence, given that environmental and ethical concerns appear to have limited effect on one's environmental impact reduction, this research investigates whether anti-consumption could be an alternative driver, without the environment being a prime motivator for consumption reduction, as it is the case for environmental and ethical concerns.

Furthermore, this study takes a fresh look at the moderating effect of emissions impact knowledge on the environmental impact of anti-consumption lifestyles. Researchers have found that consumers with more environmental knowledge tend to view individual efforts as important contributors to solving environmental problems [44]. To that end, this study proposes to conceptualize consumers' environmental knowledge by introducing a new measure seeking to attest the knowledge about individual actions' effectiveness in reducing carbon footprint, based on a recent study compiled a list of actions offering the best potential for reducing individual greenhouse gas emissions [45]. Since the most efficient actions listed involve a restriction of consumption and are similar to those adopted by anti-consumers, we propose that an increased emissions impact knowledge coupled with anti-consumption is even less harmful to the environment.

This research has important theoretical implications. First, by examining the environmental impact of anti-consumption lifestyles through a unique carbon footprint measure, it brings empirical evidence to theories that consider anti-consumption (i.e., the reduction of overall consumption) as a step towards sustainable development $[1,19]$. It also draws on previous literature claiming that the adoption of certain anti-consumption lifestyles helps reduce one's overall consumption level $[2,20]$. More specifically, this study reveals a negative relationship between tightwadism and environmental impact, which suggests that the pain of spending and a strong attachment to money seem to push some consumers to significantly reduce their overall consumption, leading to a decreased carbon footprint. Second, this study shows that a negative association between environmental impact and tightwadism is even more negative when emissions impact knowledge is higher. In other words, individuals who tend to adopt tightwadism as part of their lifestyle are not only largely predisposed to saving resources but are also engaging in even more positive environmental behaviors when they are knowledgeable about their impact. Third, we found a positive relationship between ethically minded 
consumption and environmental impact. According to this result, the more an individual claim to consume based on ethical criteria, the higher the environmental impact. This supports the idea that attempts at ethical consumption present inherent contradictions that prevent ethical concerns from dominating the purchasing decision.

This research also presents significant implications for policy makers. Despite growing ecological concerns, public policies have so far failed to influence consumer behavior in favour of the environment $[46,47]$, and current consumption trends are constantly moving away from global sustainability goals [7]. In the light of urgent and unresolved environmental challenges, this study intends to actively participate in the public debate on environmental concerns by proposing solutions to the problematic relationship between our consumerist society and the environment.

In the following section, we review the literature on anti-consumption, environmental concern, ethically minded consumption, and emissions impact knowledge. Subsequently, we present the method and test whether anti-consumption lifestyles are associated with a reduced environmental impact. In addition, we test if this association is stronger for respondents who are knowledgeable of the emissions impact of behaviors. We then compare these results with the environmental impact of environmental concern and ethically minded consumption. We conclude the paper with a discussion on future research, implications and limitations.

\section{Literature Review}

\subsection{Anti-Consumption}

Anti-consumption research focuses on phenomena that are against the acquisition, use, and dispossession of goods and services [48]. The construct, which "literally means against consumption" [23] (p. 145), refers to "a resistance to, distaste of, or even resentment of consumption" [48] (p. 121). It centres around the idea of limiting consumption; for example, restricting electricity use, but also avoiding the consumption of some goods and reclaiming a more authentic self-identity by repurposing objects and avoiding new consumption. Cherrier et al. [49] suggest that anti-consumption involves specific acts against consumption that relate to a person's self-identity project. Anti-consumers may be motivated by underlying social-psychological stresses of a consumerist-driven life. It has been argued that anti-consumption results from a process of self-inquiry triggered by the failure to feel authentic through traditional consumption activities [48].

Consumer resistance is closely and oftentimes associated with anti-consumption in the literature. Where anti-consumption constitutes a form of private but persistent refusal to go along with consuming products or services [50], consumer resistance rather refers to the voluntary opposition to marketing activities or corporations, which can lead consumers to engage in a variety of anti-consumption actions [23] and revenge behaviors against corporations [51,52]. For instance, voluntary simplifiers perform many acts of anti-consumption that are primarily motivated by a desire to reclaim an authentic sense of self, rather than to oppose a dominant force such as corporations [22].

Anti-consumption lifestyles, although difficult to endorse due to the pressures of consumerism and existing social, cultural, and identity barriers [53], are voluntarily adopted by a growing number of individuals [48] who want to avoid consumption, by either buying less and/or efficiently using resources [23]. These lifestyles reflect a general reduction in consumer activities [54]. Following this definition, we consider voluntary simplicity, tightwadism, and frugality as three distinct anti-consumption lifestyles driven by a similar feeling of opposition toward consumption and operating under personal motivations that are specific to each one of them [20]. Voluntary simplicity is the degree to which one selects a simplified lifestyle intended to maximize direct control over daily activities, while minimizing consumption and dependency $[37,38,55]$. It is centered on the idea that personal satisfaction, fulfilment, and happiness result from a commitment to the nonmaterial aspects of life [48]. Therefore, voluntary simplifiers tend to refuse to purchase items that fail to improve their level of happiness, as well as reject all consumption activities that do not correspond to their desired self-concept $[56,57]$. 
Tightwadism refers to consumers who rely on an immediate "pain of paying" to control their spending [58]. In other words, tightwads' affective reaction to spending may lead them to spend less than their more deliberative selves would prefer [36]. For them, spending money or paying for a good or service — especially consumables such as personal care, coffee, beverages, or entertainment outside the home-causes them pain [36,58]. This pain of spending money plays an important role in consumer self-regulation; hence, people who mentally impute the total cost of consumption are likely to be tightwads [58]. Therefore, consumers who experience a pain of paying may behave by accumulating wealth and avoiding unnecessary spending. Tightwadism shapes shopping behaviors and acts as an effective reminder of the sacrifice a small purchase can entail [58].

Frugality is defined as "a consumer lifestyle trait characterized by the degree to which consumers are both restrained in acquiring and in resourcefully using economic goods and services to achieve longer-term goals" [35] (p. 88). Unlike tightwadism, frugal consumers reduce consumption because they enjoy saving, not because the prospect of spending is painful [36]. In a similar fashion to Kropfeld et al. [20], we opted for these lifestyles because they met the following criteria: they have been the focus of multiple studies, they are proven to be conceptually different, and they result in similar behaviors (i.e., decrease of consumption), but for different personal reasons that do not always appear to be rooted in the quest for sustainability.

Nested within the field of consumer behavior, the study of anti-consumption aims to understand the motivations and behaviors of consumers who are against consumption and reject the consumption process in its different stages (acquisition, use, and disposal of certain goods) [22]. Recently, research has investigated the adoption of anti-consumption lifestyles as a means of achieving greater environmental sustainability $[1,2,19,20]$. With its focus on consumption reduction behaviors inherent to anti-consumption lifestyles, this research bridges the consumer behavior and sustainability fields, exploring how reduction of consumption might play a role in lowering one's ecological footprint.

Although most research in anti-consumption focuses on the reasons behind product/brand avoidance, a review of the literature indicates that practices of anti-consumption are, in fact, elements of sustainable lifestyles [2]. Black and Cherrier [2] found that living a sustainable life does not necessarily imply the consumption of green products but could rather be driven by strong self-interest and identity seeking [58]. The motivation to behave more sustainably may not stem from environmental concern in the first place [59]. Instead, anti-consumption practices of rejection, reuse, and recycle might be more sustainable because they provide consumers with opportunities to maintain consistency between their beliefs, values, and behaviors [2]. In particular, frugality [35], voluntary simplicity [19], and tightwadism [36] are primarily motivated by self-interest goals.

Consistent with the definition of anti-consumption, anti-consumers reduce their overall consumption levels (i.e., across product and service categories) as part of their lifestyle [23]. Because tightwadism, voluntary simplicity, and frugality motivate, each in their own specific way, to minimize consumption, consumers endorsing these lifestyles should possess fewer products than the average consumer. Furthermore, the strong orientation towards less consumption might lead to lower expenditures, which should, in turn, decrease the quantity of resources needed to meet consumption levels. Hence, for the above reasons, and in accordance with past research investigating frugality, voluntary simplicity, and tightwadism [20], environmental impact is expected to be negatively associated with anti-consumption lifestyles.

\subsection{Environmental Concern}

Marketing scholars often research sustainability by looking at consumers' preference for environmentally friendly choices [49]. In seeking to understand pro-environmental behavior, previous research has highlighted the importance of environmental concern [60], which could be roughly equated with an awareness of negative consequences [61] and that such awareness would activate people's norm to behave in a pro-environmental way [62]. According to Antil [63], 
consumers' environmental attitudes are expressed through their concern for the environment and are an important motive for purchasing behaviors.

Environmentally concerned individuals may be very effective in reducing their environmental impact, as they are well informed about the impact of consumption on the environment [64]. Therefore, one might expect that environmental concern is negatively associated with one's environmental impact. However, it appears that environmentally concerned individuals often find themselves on the horns of a dilemma about what to do in order to reduce their environmental impact, as they base their decisions on sometimes contradictory information [65]. Other authors add that environmentally responsible behavior usually involves difficult motivational conflicts arising from the incompatibility of collective goals to protect the environment and individuals' personal benefits [31,66]. Furthermore, there usually are external constraints to green consumerism perpetuated by the cultural, infrastructural, political, and economic circumstances in the markets and society $[67,68]$. Hence, environmentally friendly consumption may be characterized as a highly complex form of consumer behavior [65], which involves a gap between positive attitudes of consumers toward the environment and actual purchase behavior [39].

Consequently, anti-consumption lifestyles might be associated with an even lower environmental impact than environmental concern, since the broad range of anti-consumption practices allow for self-expression and provide with opportunities to show consistencies between beliefs, values, and behaviors [2]. This is contrasted with environmentally friendly consumption, where green consumers sometimes compromise parts of themselves in order to live more sustainably [69]. Therefore, we expect:

Hypothesis 1 (H1). Environmental impact will be more negatively associated with tightwadism (a), voluntary simplicity (b), and frugality (c) than with environmental concern.

\subsection{Ethically Minded Consumption}

Responses to society's ethical concerns also come from consumers who want to be informed about how the products they buy are made and who benefits from their purchases [70]. The concept of ethical consumerism has evolved considerably over the last decade [48], as it primarily focused on environmental issues (i.e., green consumerism) and came to broadly include other aspects such as animal welfare, labour standards, human rights, and health-related issues [71-73]. Cowe and Williams [74] regard ethical consumers as people who are influenced by environmental or ethical considerations when choosing products and services. Some of the ways by which consumers can accomplish this more concretely is by refusing to purchase certain products to achieve some socially responsible outcome [75] or by paying a premium for ethically made goods [76-79]. Studies have shown that many consumers have developed favorable attitudes towards ethical products and companies with socially responsible practices $[80,81]$, and they believe that they have the power to change companies' behaviors [82].

However, there seems to be a difference between what consumers say about the importance of ethical consumerism and their actual purchasing behavior, as the market share of ethical products and brands remains low $[83,84]$. Therefore, the attitude-behavior gap described previously is not unique to environmental concern. This consumer attitude-behavior gap with respect to ethical issues $[82,85]$ has been noted by several researchers [27-31,70]. Ethical intentions stated in surveys are rarely acted upon in terms of actual ethical choices and purchases [42]. It has been found that ethical consumers sometimes leave ethics aside when a decision involves a trade-off between ethical and traditional purchasing criteria, such as price or availability [86]. Any attempt to consume ethically may reveal inherent tensions among one's divergent concerns [87]. For example, one's goal of reducing food miles may conflict with supporting developing countries, a societal kind of concern. Therefore, consuming ethically often posits consistency challenges to consumers, and it is likely that corporate 
social responsibility might not be the dominant criterion at the time of an ethical consumer's purchase decision [39].

Hypothesis 2 (H2). Environmental impact will be more negatively correlated with tightwadism (a), voluntary simplicity $(b)$ and frugality $(c)$ than with ethically minded consumption.

\subsection{Emissions Impact Knowledge as a Moderator}

Studies have reported that consumers with high environmental awareness are more likely to adopt environmentally friendly behaviors [32-34], since they are more aware of their potential damage to the environment $[88,89]$. Some researchers have also found that individuals with more environmental knowledge tend to view individual efforts as important factors that can contribute to solving environmental problems [44].

When evaluating different behavioral alternatives to adopt to reduce environmental footprint, a person's knowledge as to their relative conservation effectiveness becomes essential [90]. One may try, for example, to save more energy, whether by purchasing a fuel-efficient automobile or by limiting driving. In that respect, Wynes and Nicholas [45] have compiled various individual actions' potential in reducing negative emissions on the environment. The most effective emission-reduction actions listed, which help save more than $0.8 \mathrm{tCO}_{2} \mathrm{e}$ per year, can contribute to systemic change and substantially reduce annual personal emissions. These actions (i.e., having one fewer child, living car-free, avoiding airplane travel, and eating a plant-based diet) imply a significant reduction in consumption and lifestyle orientation toward restriction. They contrast with less effective actions in terms of emissions reduction such as recycling or upgrading lightbulbs (only $0.2 \mathrm{tCO}_{2} \mathrm{e}$ saved per year).

Consumption reduction behaviors are easier to incorporate into everyday habits at no upfront costs [91], as opposed to efficiency improvements that generally involve more research, effort, and higher expenses (e.g., getting a new energy-efficient refrigerator). Since anti-consumption lifestyles involve prioritizing consumption reduction behaviors (i.e., high impact actions such as avoiding driving) over efficiency improvement actions (i.e., moderate to low impact actions such as upgrading lightbulbs), we argue that emissions impact knowledge will moderate the influence of anti-consumption on environmental impact. That is, when emissions impact knowledge is high, anti-consumption lifestyles should be associated with reduced environmental impact.

Hypothesis 3 (H3). Environmental impact will be more negatively associated with tightwadism (a), voluntary simplicity (b), and frugality (c) when emissions impact knowledge is high.

\section{Method}

\subsection{Participants and Procedure}

A sample of 357 participants completed the online survey. These participants were recruited via Qualtrics panel, and they were all located in California. A single state was selected to standardize costs of electricity, transportation, and other categories of expenses involved in the carbon footprint calculator, since respondents were asked to indicate the average amount spent (\$USD) by their household on different categories of products and services in the last twelve months. Items measuring participants' scores on the anti-consumption lifestyles, as well as environmental and ethical concerns, were presented to participants before the spending questions to minimize social desirability. Questions within these two sections appeared in a random order to minimize order response bias. Randomization was insured by randomly distributing the questionnaire across members of the panel.

Seven participants were excluded because they failed the attention manipulation check [92] or provided unlikely spending habits (e.g., participants who indicated driving over 100,000 miles per year). Eighty percent of the participants were female. Respondents' mean age was 46 years old (range: 18-91) with $41 \%$ of them with a university degree. Their reported annual revenues (before taxes) 
show significant variance; while $26 \%$ earn less than US $\$ 30,000$ per household per year, $24 \%$ earn more than $\$ 90,000$. Finally, there is an average of three people per household among participants (standard deviation $=1.77$ ), and more than half of them are married or common-law partners.

\subsection{Measures}

To measure the constructs related to the anti-consumption lifestyles as well as environmental and ethical concerns, we used multi-item self-reported scales that have been tested and reviewed in past research and proved to be valid and reliable. For tightwadism, we used the four-item scale by Rick et al. [36]; for frugality, the eight-item scale developed by Lastovicka et al. [35]; and for voluntary simplicity, the nine-item scale used by Iwata [37,93] as adapted by Nepomuceno and Laroche [94]. We measured environmental concern with the New Ecological Paradigm scale by Dunlap et al. [95], and we measured ethically minded consumption with the scale by Sudbury-Riley and Kohlbacher [96].

We tested the emissions impact knowledge by asking participants to rate twelve individual actions according to their perceived effectiveness in reducing personal emissions. Participants had to select, for each of them, on a Likert-type frequency scale ranging from " 1 " (the least effective action to reduce carbon footprint) to "7" (the most effective action to reduce carbon footprint), the figure that best matches their perception of reality. This scale estimated the knowledge they have about the extent to which each individual action can reduce one's negative impact on the environment, as listed by Wynes and Nicholas [45]. In order to measure the participant's total emissions impact knowledge, the numbers selected for each item were subtracted from their real score (refer to Table 1), which resulted in a score that ranged from 0 (right answer; no difference with real score) to a positive or negative score between 1 to 6 (wrong answer; action effectiveness is overrated or underrated). The twelve scores were combined in an index of emissions impact knowledge, where a low index represented an adequate knowledge and a high index represented little knowledge. This method was preferred to existing scales, because it measures participants' real knowledge of emissions impact as opposed to a self-report of their self-perceived knowledge.

Environmental impact was measured with a carbon footprint calculator [97] that uses emissions factors considering all greenhouse gases (i.e., $\mathrm{CO}_{2}, \mathrm{~N}_{2} \mathrm{O}$, methane, etc.). Participants indicated the amount spent on numerous activities, products, and services (e.g., plane trips, energy consumption, food and clothes, etc.) in the last 12 months. Different steps were taken to help respondents estimate their expenses as accurately and easily as possible. For example, instead of having to report the number of $\mathrm{kWh}$ of electricity consumed by their household in the past year, which is difficult to know for the average consumer, respondents had to indicate the amount spent on electricity in \$USD. They were invited to do so by consulting their electricity company's website, bank account statements, or electricity bills. Using the price of electricity in California during the data collection period, we converted respondents' expenses into $\mathrm{kWh}$, which we entered in the calculator. The calculator used the amount in $\mathrm{kWh}$ to calculate the amount of $\mathrm{tCO}_{2}$ derived from electricity consumption.

To allow fair comparisons between respondents, the amount spent in certain categories was divided by the number of individuals living in the same household (refer to Table 2). For example, this was done with the amount spent on electricity and groceries (for a full list, please refer to Table 2). In order to estimate the total carbon footprint generated by the respondent, the carbon footprint calculator added, in tons of $\mathrm{CO}_{2}$ emitted for a full year, the score obtained in each of the consumption categories listed in Table 2. Nonetheless, we observed that the data distribution was skewed (skewness $=2.55$ ), so we transformed the total footprint calculator by calculating its log. This new value was no longer skewed (skewness $<1$ ) and was used in the analyses reported below. The same issue was observed for the remaining categories of expenditures listed in Table 2, and the same solution was adopted for each category.

The survey also included questions assessing the participants' demographic and socioeconomic dimensions with respect to their age, income, highest level of education completed, gender, US state of residence, and marital status. These sociodemographic characteristics were collected to control 
the effects of these variables on environmental impact and to detect clues as to the use of potential moderators that can be tested by subsequent research.

\subsection{Validity and Reliability}

The Cronbach alphas are equal to 0.81 for voluntary simplicity, 0.92 for frugality, 0.69 for tightwadism, 0.92 for ethically minded consumption, and 0.83 for environmental concern, thereby confirming the respective reliability of each measure. Three of the five constructs present good convergent validity, with coefficients exceeding the recommended minimum of 0.5 (average variance extracted $[\mathrm{AVE}]$ for frugality $=0.700$; AVE for tightwadism $=0.556$; AVE for ethically minded consumption $=0.592)$. Voluntary simplicity and environmental concern share only $41.7 \%$ and $46.7 \%$ variance with their respective measures. The conditions of discriminant validity were met; the AVE for each construct is higher than the squared correlation between them [98]. These squared correlations ranged between 0 and 0.21 , remaining lower than the average variance extracted. The items used in the scales along with relevant statistics are presented in Table 3.

Table 3. Items used to measure each scale and respective statistical parameters.

\begin{tabular}{|c|c|c|c|c|}
\hline & & $\begin{array}{c}\text { Factor } \\
\text { Loading }\end{array}$ & Mean & $\begin{array}{l}\text { Standard } \\
\text { Deviation }\end{array}$ \\
\hline \multirow{8}{*}{ Frugality Scale } & $\begin{array}{l}\text { If you take good care of your possessions, you will } \\
\text { definitely save money in the long run. }\end{array}$ & 0.785 & 6.179 & 1.553 \\
\hline & $\begin{array}{l}\text { There are many things that are normally thrown away } \\
\text { that are still quite useful. }\end{array}$ & 0.685 & 5.501 & 1.638 \\
\hline & Making better use of my resources makes me feel good. & 0.851 & 5.944 & 1.555 \\
\hline & $\begin{array}{l}\text { If you can re-use an item you already have, there's no } \\
\text { sense in buying something new. }\end{array}$ & 0.820 & 5.818 & 1.619 \\
\hline & I believe in being careful in how I spend my money. & 0.858 & 5.843 & 1.609 \\
\hline & I discipline myself to get the most from my money. & 0.818 & 5.479 & 1.626 \\
\hline & $\begin{array}{l}\text { I am willing to wait on a purchase I want so that I can } \\
\text { save money. }\end{array}$ & 0.840 & 5.569 & 1.598 \\
\hline & $\begin{array}{l}\text { There are things I resist buying today so I can save for } \\
\text { tomorrow. }\end{array}$ & 0.822 & 5.510 & 1.657 \\
\hline \multirow{9}{*}{$\begin{array}{c}\text { Voluntary } \\
\text { Simplicity Scale }\end{array}$} & $\begin{array}{l}\text { I fully adhere to a simple lifestyle and only buy } \\
\text { necessities. }\end{array}$ & 0.793 & 3.277 & 1.146 \\
\hline & I never buy impulsively. & 0.629 & 2.888 & 1.182 \\
\hline & $\begin{array}{l}\text { I only shop after seriously considering whether or not an } \\
\text { item is absolutely necessary. }\end{array}$ & 0.719 & 3.375 & 1.086 \\
\hline & $\begin{array}{l}\text { I am more concerned with personal growth and } \\
\text { fulfilment than with material possessions. }\end{array}$ & 0.568 & 3.798 & 1.091 \\
\hline & $\begin{array}{l}\text { Even when I have money, I never buy things } \\
\text { unexpectedly. }\end{array}$ & 0.710 & 3.070 & 1.205 \\
\hline & I want to grow my own food in the future. & 0.536 & 2.986 & 1.474 \\
\hline & $\begin{array}{l}\text { In the future, I want to produce my own goods (such as } \\
\text { clothes and tools). }\end{array}$ & 0.471 & 2.261 & 1.295 \\
\hline & $\begin{array}{l}\text { I would adopt a simple lifestyle even if I were able to } \\
\text { live extravagantly. }\end{array}$ & 0.716 & 3.283 & 1.176 \\
\hline & $\begin{array}{l}\text { A simple lifestyle makes you financially independent } \\
\text { from others. }\end{array}$ & 0.605 & 3.765 & 1.074 \\
\hline
\end{tabular}


Table 3. Cont.

\begin{tabular}{|c|c|c|c|c|}
\hline & & $\begin{array}{l}\text { Factor } \\
\text { Loading }\end{array}$ & Mean & $\begin{array}{l}\text { Standard } \\
\text { Deviation }\end{array}$ \\
\hline \multirow{15}{*}{$\begin{array}{l}\text { Environmental } \\
\text { Concern }\end{array}$} & $\begin{array}{l}\text { We are approaching the limit of the number of people } \\
\text { the earth can support. }\end{array}$ & 0.508 & 3.891 & 1.952 \\
\hline & $\begin{array}{l}\text { Humans have the right to modify the natural } \\
\text { environment to suit their needs. (R)* }\end{array}$ & - & - & - \\
\hline & $\begin{array}{l}\text { When humans interfere with nature it often produces } \\
\text { disastrous consequences. }\end{array}$ & 0.739 & 4.886 & 1.959 \\
\hline & $\begin{array}{l}\text { Human ingenuity will insure that we do NOT make the } \\
\text { earth unliveable. }(\mathrm{R})^{*}\end{array}$ & - & - & - \\
\hline & Humans are severely abusing the environment. & 0.804 & 5.046 & 1.972 \\
\hline & $\begin{array}{l}\text { The earth has plenty of natural resources if we just learn } \\
\text { how to develop them. }(\mathrm{R})^{*}\end{array}$ & - & 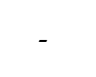 & - \\
\hline & $\begin{array}{l}\text { Plants and animals have as much rights as humans to } \\
\text { exist. }\end{array}$ & 0.640 & 5.174 & 1.994 \\
\hline & $\begin{array}{l}\text { The balance of nature is strong enough to cope with the } \\
\text { impacts of modern industrial nations. (R) }{ }^{*}\end{array}$ & - & - & - \\
\hline & $\begin{array}{l}\text { Despite our special abilities humans are still subject to } \\
\text { the laws of nature. }\end{array}$ & 0.580 & 5.334 & 1.796 \\
\hline & $\begin{array}{l}\text { The so-called "ecological crisis" facing humankind has } \\
\text { been greatly exaggerated. }(\mathrm{R}) \text { * }\end{array}$ & - & - & -1 \\
\hline & $\begin{array}{l}\text { The earth is like a spaceship with very limited room and } \\
\text { resources. }\end{array}$ & 0.628 & 3.786 & 1.846 \\
\hline & Humans were meant to rule over the rest of nature. $(R)^{*}$ & - & - & - \\
\hline & The balance of nature is very delicate and easily upset. & 0.704 & 4.403 & 1.906 \\
\hline & $\begin{array}{l}\text { Humans will eventually learn enough about how nature } \\
\text { works to be able to control it. (R)* }\end{array}$ & - & - & - \\
\hline & $\begin{array}{l}\text { If things continue on their present course, we will soon } \\
\text { experience a major ecological catastrophe. }\end{array}$ & 0.757 & 4.677 & 2.034 \\
\hline \multirow{4}{*}{$\begin{array}{l}\text { Tightwadism } \\
\text { Scale }\end{array}$} & $\begin{array}{l}\text { Which of the following descriptions fits you better? } \\
\text { Tightwad - Spendthrift (R) }\end{array}$ & 0.827 & 5.553 & 2.039 \\
\hline & Do you have trouble limiting your spending? (R) & 0.772 & 2.680 & 0.925 \\
\hline & Do you have trouble spending money? & 0.647 & 2.784 & 0.944 \\
\hline & Who are you more similar to, Mr. A or Mr. B? & 0.694 & 3.253 & 1.244 \\
\hline \multirow{10}{*}{$\begin{array}{c}\text { Ethical } \\
\text { Consumption }\end{array}$} & $\begin{array}{l}\text { When there is a choice, I always choose the product that } \\
\text { contributes to the least amount of environmental } \\
\text { damage. }\end{array}$ & 0.813 & 3.233 & 1.208 \\
\hline & I have switched products for environmental reasons. & 0.823 & 3.253 & 1.295 \\
\hline & $\begin{array}{l}\text { that some products can cause, I do not purchase those } \\
\text { products. }\end{array}$ & 0.802 & 3.534 & 1.211 \\
\hline & $\begin{array}{l}\text { I do not buy household products that harm the } \\
\text { environment. }\end{array}$ & 0.757 & 3.219 & 1.197 \\
\hline & $\begin{array}{l}\text { Whenever possible, I buy products packaged in reusable } \\
\text { or recyclable containers. }\end{array}$ & 0.763 & 3.750 & 1.173 \\
\hline & $\begin{array}{l}\text { I make every effort to buy paper products (toilet paper, } \\
\text { tissues, etc.) made from recycled paper. }\end{array}$ & 0.756 & 3.157 & 1.291 \\
\hline & $\begin{array}{l}\text { I will not buy a product if I know that the company that } \\
\text { sells it is socially irresponsible. }\end{array}$ & 0.797 & 3.351 & 1.293 \\
\hline & $\begin{array}{l}\text { I do not buy products from companies that I know use } \\
\text { sweatshop labor, child labor, or other poor working } \\
\text { conditions. }\end{array}$ & 0.632 & 3.744 & 1.311 \\
\hline & $\begin{array}{l}\text { I have paid more for environmentally friendly products } \\
\text { when there is a cheaper alternative. }\end{array}$ & 0.801 & 3.289 & 1.284 \\
\hline & $\begin{array}{l}\text { I have paid more for socially responsible products when } \\
\text { there is a cheaper alternative. }\end{array}$ & 0.786 & 3.258 & 1.292 \\
\hline
\end{tabular}

$(\mathrm{R})=$ Denotes reversed items. ${ }^{*}=$ Denote items removed from the analyses because the factor loading obtained was below 0.30 or because the item loaded in multiple factors. The statistics of the remaining items were calculated after the elimination of these items. 


\section{Results}

\subsection{Environmental Impact of Lifestyles}

Our first analysis aims at testing the association between anti-consumption lifestyles on environmental impact (see Table 4). In accordance with our prediction, we found that tightwadism correlates negatively with overall environmental impact $(r=-0.12, p=0.03)$, thereby confirming past research [20]. We found the strongest correlation for the other expenses category $(r=-0.14, p=0.01)$. A detailed analysis considering each product and service listed in the other expenses category showed that tightwadism is negatively associated with spending in food and beverages $(r=-0.20 ; p<0.001)$, clothing $(r=-0.33 ; p<0.001)$, paper-based products $(r=-0.14 ; p=0.04)$, furniture $(r=-0.18 ; p=0.02)$, pharmaceuticals $(r=-0.32 ; p<0.001)$, telecommunications $(r=-0.15 ; p<0.01)$, insurance $(r=-0.13$; $p=0.02)$, and marginally associated with spending in hotels $(r=-0.10 ; p=0.07)$. These findings indicate that a tightwad perspective tends to lower consumption of several different kinds of products and services, putting a downward pressure on overall environmental impact.

We found no significant correlation between voluntary simplicity and environmental impact $\left(r=-0.07 ; p=0.17 ; \mathrm{CI}_{95 \%}:-0.221\right.$ to -0.0164$)$. However, we found that the other expenses category $\left(r=-0.14, p=0.01 ; \mathrm{CI}_{95 \%}:-0.24\right.$ to -0.037$)$ and the flight category $\left(r=-0.17 ; p=0.03 ; \mathrm{CI}_{95 \%}:-0.269\right.$ to $-0.067)$ were negatively associated with voluntary simplicity. A detailed analysis within other expenses category shows that voluntary simplicity is negatively associated with spending in computer equipment $\left(r=-0.17 ; p=0.03 ; \mathrm{CI}_{95 \%}:-0.269\right.$ to -0.067$)$, furniture $\left(r=-0.18 ; p=0.02 ; \mathrm{CI}_{95 \%}:-0.279\right.$ to -0.078$)$, hotels $\left(r=-0.15 ; p=0.04 ; \mathrm{CI}_{95 \%}:-0.25\right.$ to -0.047$)$, and marginally associated with spending in food and beverages $\left(r=-0.10 ; p=0.08 ; \mathrm{CI}_{95 \%}:-0.202\right.$ to 0.004$)$, clothing $\left(r=-0.11 ; p=0.08 ; \mathrm{CI}_{95 \%}:-0.211\right.$ to -0.006$)$, and paper-based products $\left(r=-0.11 ; p=0.09 ; \mathrm{CI}_{95 \%}:-0.211\right.$ to -0.006$)$.

In addition, we found no significant association between frugality and environmental impact $\left(r=0.01 ; p=0.86 ; \mathrm{CI}_{95 \%}:-0.094\right.$ to 0.114$)$. Frugality is marginally associated with car and motorcycle usage ( $r=0.10 ; p=0.08 ; \mathrm{CI}_{95 \%}:-0.202$ to -0.004$)$, but not significantly associated with any of the categories listed in Table 4, nor with any of the product and services listed in the other expenses category $(p>0.05)$. Overall, our findings with frugality and voluntary simplicity do not support expectations that environmental impact is lower for these anti-consumption lifestyles.

We found that environmental concern was not associated with environmental impact $(r=0.03$; $p=0.58 ; \mathrm{Cl}_{95 \%}:-0.076$ to 0.135$)$. Environmental concern is also not significantly associated with any of the categories listed in Table $1(p>0.05)$. We found only a marginally negative association between motor vehicles $\left(r=-0.137 ; p=0.06\right.$; $\mathrm{CI}_{95 \%}:-0.272$ to 0.007$)$ and banking and financial sector $(r=-0.136$; $p=0.06$; $\mathrm{CI}_{95 \%}:-0.211$ to 0.067$)$ for the analyses with the products and services within other expenses category. Given that voluntary simplicity and frugality were also not associated with environmental impact, H1b and H1c were not supported. However, we did find support for H1a, because tightwadism is negatively associated with environmental impact, whereas environmental concern does not.

The relationship between ethically minded consumption and environmental impact is significant and positive ( $r=0.11 ; p=0.03 ; \mathrm{CI}_{95 \%}: 0.211$ to 0.006$)$. This finding supports $\mathrm{H} 2 \mathrm{a}, \mathrm{H} 2 \mathrm{~b}$, and $\mathrm{H} 2 \mathrm{c}$, albeit in a surprising way, as we did not expect to find a positive association. In any case, this finding supports the idea that adopting ethical behaviors is actually damaging to the environment. The analyses with the categories of expenses showed that only other expenses category is marginally associated with ethical consumption ( $r=0.10 ; p=0.07 ; \mathrm{CI}_{95 \%}:-0.202$ to 0.004$)$, and that this association is driven by spending in food and beverages ( $r=0.09 ; p=0.08 ; \mathrm{CI}_{95 \%}:-0.014$ to 0.192$)$. The remaining categories are not associated with ethical consumption. 
Table 4. Correlations between Anticonsumption Lifestyles, Environmental Concern, and Ethically Minded Consumption with Environmental Impact and Expenditures Categories.

\begin{tabular}{|c|c|c|c|c|c|c|c|}
\hline & $M$ & $S D$ & Tightwadism & $\begin{array}{l}\text { Voluntary } \\
\text { Simplicity }\end{array}$ & Frugality & $\begin{array}{l}\text { Environmental } \\
\text { Concern }\end{array}$ & $\begin{array}{l}\text { Ethically Minded } \\
\text { Consumption }\end{array}$ \\
\hline Overall Environmental Impact & 9.57 & 8.08 & $-0.12 *$ & -0.07 & 0.01 & 0.03 & $0.11 *$ \\
\hline Environmental Impact of other expenses & 4.44 & 4.09 & $-0.14 * *$ & $-0.14 * *$ & 0.03 & 0.05 & $0.10^{+}$ \\
\hline - Food and beverages & 5.46 & 4.55 & -0.20 ** & $-0.10^{+}$ & 0.018 & 0.070 & $0.09^{+}$ \\
\hline - Pharmaceuticals & 0.02 & 0.003 & $-0.32 * *$ & -0.01 & -0.056 & 0.100 & 0.105 \\
\hline - Clothing, textiles and shoes & 0.25 & 0.38 & -0.33 ** & $-0.11^{\dagger}$ & -0.039 & -0.020 & 0.008 \\
\hline - Telephone, mobile/cellphone call costs & 0.73 & 0.72 & $-0.15^{* *}$ & -0.057 & -0.074 & -0.080 & -0.020 \\
\hline - Hotel, restaurants and pubs & 0.57 & 1.08 & $-0.10^{+}$ & $-0.15^{*}$ & 0.008 & 0.102 & -0.048 \\
\hline - Banking and financial sector (mortgage and interest payments) & 1.26 & 3.08 & 0.033 & -0.047 & 0.061 & $-0.136^{+}$ & -0.017 \\
\hline - Insurance & 0.67 & 1.32 & $-0.13 *$ & 0.053 & 0.019 & -0.031 & 0.039 \\
\hline - Paper-based products (e.g., books and magazines) & 0.04 & 0.07 & $-0.14 *$ & $-0.11^{\dagger}$ & -0.084 & -0.000 & 0.010 \\
\hline - Computer and equipment & 0.12 & 0.25 & -0.081 & $-0.17 *$ & -0.004 & -0.065 & -0.075 \\
\hline - Television, radio and phone (equipment) & 0.14 & 0.27 & -0.152 & 0.033 & 0.095 & -0.077 & -0.053 \\
\hline - Motor vehicles (excluding fuel costs) & 0.50 & 1.06 & 0.009 & -0.092 & -0.049 & $-0.137^{\dagger}$ & 0.019 \\
\hline - Furniture and other manufactured good & 0.23 & 2.15 & $-0.18^{*}$ & $-0.18 *$ & 0.038 & 0.017 & -0.016 \\
\hline - Education & 0.28 & 1.14 & 0.027 & -0.074 & -0.050 & 0.145 & -0.115 \\
\hline Environmental impact of household energy & 2.32 & 3.31 & $-0.10^{+}$ & 0.01 & 0.03 & -0.04 & -0.003 \\
\hline Environmental impact of flights & 0.88 & 2.63 & -0.09 & -0.17 * & -0.08 & -0.01 & 0.003 \\
\hline Environmental impact of private transportation (car and motorbike usage) & 1.45 & 1.97 & -0.06 & 0.01 & $0.10+$ & 0.005 & -0.04 \\
\hline Environmental impact of public transportation usage & 0.44 & 3.54 & -0.02 & -0.06 & -0.15 & -0.01 & -0.07 \\
\hline
\end{tabular}

${ }^{+} p<0.10 .{ }^{*} p<0.05 .{ }^{* *} p<0.01$. 


\subsection{Moderating Role of Emissions Impact Knowledge}

We conducted a simple moderation analysis using 10,000 bootstrap resamples (PROCESS model 1) [99]. It examined how environmental impact was influenced by anti-consumption lifestyles, environmental concern, and ethical consumption for different levels of emissions impact knowledge. In these analyses, we included income, age, education, sex, and marital status as control variables. Emissions impact knowledge was included as a moderator. In addition, environmental concern, ethically minded consumption, and the anti-consumption lifestyles (tightwadism, frugality, and voluntary simplicity) were included as independent variables. We found that tightwadism is negatively associated with environmental impact $\left(\mathrm{b}=-0.0124 ; \mathrm{CI}_{95 \%}:-0.0203\right.$ to -0.0046$)$. Furthermore, the interaction between tightwadism and emissions impact knowledge was significantly associated with environmental impact ( $\mathrm{b}=0.0011 ; \mathrm{CI}_{95 \%}: 0.0001$ to 0.0020$)$. Specifically, tightwadism was negatively associated with environmental impact among highly $\left(-1 S D ; \mathrm{CI}_{95 \%}\right.$ : -0.0291 to -0.0104$)$ and average $\left(\mathrm{CI}_{95 \%}\right.$ : -0.0203 to -0.0046) emissions knowledgeable participants. Among participants with low emission impact knowledge $(+1 S D)$, there was no significant association between tightwadism and environmental impact ( $\mathrm{b}=-0.0051 ; \mathrm{CI}_{95 \%}$ : -0.0160 to 0.0058$)$. Note that the environmental knowledge scale is inversed, thus a high score in environmental impact knowledge denotes low knowledge about one's environmental impact. Overall, these results are in line with H3a, suggesting that tightwads have an even lower environmental impact when they are knowledgeable about their emissions.

The analyses conducted with frugality, voluntary simplicity, environmental concern, and ethical consumption yielded similar results. That is, none of these constructs were significantly associated with environmental impact (all $p>0.11$ ). Furthermore, the interaction between these constructs and emission impact knowledge were not significantly associated with environmental impact (all $p>0.32$ ). Therefore, we found no support for $\mathrm{H} 3 \mathrm{~b}$ and $\mathrm{H} 3 \mathrm{c}$, which is line with recent research [20].

\section{Discussion}

Building on previous literature defending anti-consumption as a path to more sustainable societies $[1,2,20]$, this study investigates the environmental impact of tightwadism, frugality, and voluntary simplicity, as well as environmental concern and ethically minded consumption. The results reveal that environmental impact is negatively associated with tightwadism, unrelated to frugality, voluntary simplicity, and environmental concern, and positively associated with ethically minded consumption. We also looked into the moderating role of emissions impact knowledge between anti-consumption lifestyles and environmental impact and found that tightwadism is associated with lower environmental impact among highly emissions knowledgeable consumers. As predicted, exploring anti-consumption lifestyles in a sustainable development perspective highlights the importance of consumption reduction's contribution to the deceleration of environmental degradation. The findings reported in this research demonstrate the downstream consequences of adopting a tightwadism lifestyle and its impact on environmental sustainability.

\subsection{Environmental Impact of Anti-Consumption Lifestyles}

According to the results of the current investigation, the negative relationship observed between tightwadism and environmental impact is in line with past research [20]. This finding provides additional evidence that limiting consumption in the manner of tightwadism succeeds in reducing harmful impacts on the environment. As hypothesized, the pain of spending experienced by tightwads may lead to a greater reduction in environmental impact than voluntary simplicity, frugality, environmental concern, or ethically-minded consumption. It appears the negative emotions that arise from the prospect of spending play an important role in consumers' ability to self-regulate [58]. Tightwads' aversion toward spending and strong desire to avoid it drives them to significantly reduce their overall consumption which, in turn, may explain why they would have a significantly lower environmental impact than other consumers. 
Confirming a past study stating that frugality was unrelated to ecological impact [20], no significant relationship was found between frugality and environmental impact in this current investigation. Past literature suggests that individuals who adopt a frugal lifestyle view consumption as trivial and superficial [100] and undertake to reduce their consumption in the short term [35]. However, a decline in their consumption could be offset by an increase in their long-term expenditures, as some individuals refuse to submit to their short-term whims in order to achieve a goal of greater value, potentially of material nature [35]. Thus, even if frugal people adopt a way of life in which they seek to limit their consumption, they could commit themselves to higher expenditures in the long run, or even increase their spending on durable goods, as long as these purchases allow them to avoid waste and superficial costs [100].

In the case of voluntary simplicity, we observed no statistically significant relationship with environmental impact. Since consumption reduction is not a goal in itself for voluntary simplicity but rather a way to lead a fulfilling life, individuals who adopt this anti-consumption lifestyle might still spend on goods or services that fit their self-concept [56,57]. For instance, they might be spending money on experience (i.e., travel overseas), rather than material possessions.

\subsection{Environmental Concern, Ethically Minded Consumption, and Emissions Impact Knowledge}

This study also reveals that environmentally concerned consumers do not have a lower environmental impact. This reinforces the view that attitude-behavior inconsistencies exist, at least in part, because positive attitudes toward the environment will not necessarily lead to a reduction in environmental impact. A similar conclusion can be drawn from the statistically significant and positive relationship between ethically minded consumption and environmental impact. The more individuals claim to consume based on ethical criteria, the higher their environmental impact. These results suggest that displaying pro-environmental or ethical attitudes might not be enough to reduce the negative impact of consumption on the environment.

Although environmental concern and ethical consumption can be perceived as models of sustainable consumption to achieve, our results demonstrate that their ecological contribution is limited, especially when compared to that of tightwadism. It would seem, then, that even high environmental or ethical concern may be outweighed by other needs and desires, and that many conflicting factors may compete to shape their daily decisions and actions of consumers [101]. For example, the desire to travel to visit one's family abroad could take precedence over the environmentally concerned individuals' responsibility to reduce air travel to minimize their contribution to global warming. Therefore, we point to the need for other elements with the potential to bring people to act in an ecological way, without environmental or ethical concern being the central solution.

Another possible explanation for the findings with environmental concern and ethically minded consumption relates to the "negative footprint illusion" effect, as described by Kim and Schudt [102]. This bias in judgment is such that when consumers purchase an environmentally friendly product, they become insensitive to the quantity of usage or purchase of such product. In other words, though consumers have purchased a more environmentally friendly option, they end-up using it or purchasing it more, which ultimately increases their environmental impact.

The moderation analysis allowed us to conclude that environmental impact is more negatively associated with tightwadism when emissions impact knowledge is high. This result suggests that knowing the most effective emission-reduction actions is likely to encourage consumers who adopt a tightwad lifestyle to restrict their consumption to a greater degree. This finding is important, as it supports previous studies suggesting that understanding how to solve environmental problems increases the likelihood to take action to protect the environment $[89,101,103]$.

\subsection{Research Limitations}

The results of this research should be evaluated considering a few methodological limitations. First, one should keep in mind this study's limitations related to sample size, composition, and location. 
As in any study with similar methods, the results presented in this paper should be interpreted with care and may not be generalizable to other contexts. Future research should attempt to recruit larger samples and more diverse profiles of respondents. Please refer to Table 5 for a comparison of the demographics of the sampled population and the general population in the United States. Of note, the current sample is older, has considerably more women, and has lower household income. Despite these limitations, it is important to note that some of the results presented in this article are consistent with Kropfeld et al. [20], which was conducted using a different sample (Germans) and method (a more limited carbon footprint calculator). This provides further evidence that the adoption of an anti-consumption lifestyle (i.e., tightwadism) may lead to a significant reduction in one's carbon footprint.

Table 5. Demographics of recruited participants and national average of the United States [104-108].

\begin{tabular}{|c|c|c|c|}
\hline Current Sample & & National Average (USA) & \\
\hline Education & & Education & \\
\hline Less than High School Degree & $1.43 \%$ & Less than High School Degree & $9.90 \%$ \\
\hline High School Graduate & $14.57 \%$ & At least High School Degree, but not more & \\
\hline Some College/Associate's Degree & $41.43 \%$ & than college degree & $54.10 \%$ \\
\hline Undergraduate University Degree (Bachelor) & $27.43 \%$ & & \\
\hline Graduate University Degree (Master/MBA) & $12.57 \%$ & College Graduate or More & $36.00 \%$ \\
\hline $\mathrm{PhD}$, Law, or Medical Degree & $2.29 \%$ & & \\
\hline I don't want to answer this question & $0.28 \%$ & & \\
\hline Sex & & Sex & \\
\hline Male & $17.71 \%$ & Male & $48.90 \%$ \\
\hline Female & $81.29 \%$ & Female & $51.10 \%$ \\
\hline Average Age & 45.69 & Average Age & 38.4 \\
\hline Marital Status & & Marital Status & \\
\hline Single & $27.51 \%$ & Single & $32.40 \%$ \\
\hline Married & $44.41 \%$ & & \\
\hline Domestic partnership/Civil union & $7.45 \%$ & Married; Domestic partnership/Civil union & $52.29 \%$ \\
\hline Divorced/Separated & $17.19 \%$ & Divorced/Separated & $9.66 \%$ \\
\hline Widow & $2.87 \%$ & Widow & $5.65 \%$ \\
\hline I don't want to answer this question & $0.57 \%$ & & \\
\hline Income & & Income & \\
\hline I have no income & $0.86 \%$ & Under $\$ 15,000$ & $9.10 \%$ \\
\hline Between $\$ 1$ and $\$ 30,000$ & $23.71 \%$ & Between $\$ 15,000$ and $\$ 24,999$ & $8.00 \%$ \\
\hline Between $\$ 30,001$ and $\$ 60,000$ & $27.43 \%$ & Between $\$ 25,000$ and $\$ 34,999$ & $8.30 \%$ \\
\hline Between $\$ 60,001$ and $\$ 90,000$ & $18.00 \%$ & Between $\$ 35,000$ and $\$ 49,999$ & $11.70 \%$ \\
\hline Between $\$ 90,001$ and $\$ 120,000$ & $13.14 \%$ & Between $\$ 50,000$ and $\$ 74,999$ & $16.50 \%$ \\
\hline More than $\$ 120,000$ & $12.57 \%$ & Between $\$ 75,000$ and $\$ 99,999$ & $12.30 \%$ \\
\hline \multirow[t]{2}{*}{ I don't want to answer this question } & $4.29 \%$ & Between $\$ 100,000$ and $\$ 149,999$ & $15.50 \%$ \\
\hline & & $\begin{array}{c}\text { Between } \$ 150,000 \text { and } \$ 199,999 \\
\text { More than } \$ 200,000\end{array}$ & $\begin{array}{l}8.30 \% \\
10.3 \%\end{array}$ \\
\hline
\end{tabular}

Second, participants' answers may partly reflect their desire to project a positive image of themselves. The social desirability or self-presentation bias is inherent in all surveys that concern consumers' willingness to adopt socially responsible consumption behaviors [43,109]. To alleviate this issue, we reiterated that the data collection was anonymous, and participants' privacy was safeguarded.

Third, although the carbon footprint calculator used in this study [98] is reliable and efficient in terms of broad inclusion of carbon emission sources and depth measurement [25], the level of detail gathered from the participants has some limitations. For example, participants had to provide details about their travel itineraries by plane over the last 12 months, specifying the city of departure and destination, the stops made, and class type they travelled in (e.g., economy, business, etc.). This allowed 
us to quantify each plane trip individually. However, such a level of specificity was not possible for other categories, such as home energy. Expenses related to home energy were reported by energy type (e.g., electricity, natural gas, coal, etc.) for a typical month in the past year. Assumptions had to be made; the amount of total energy consumed by a household in a year is the sum of 12 identical consumption months, and the amount of energy consumed by an individual is equivalent to the total energy consumed by its household divided by the number of people that live together. Needless to say, this provided, at best, a rough measure of one's carbon footprint.

Fourth, the carbon footprint calculator made no distinction between a green or ethical product and a regular one. The environmental footprint could differ greatly depending on the raw materials that make up the product, or its recyclability degree, for example. A product's carbon footprint is calculated using the amount spent on that product, without considerations for ethical or green aspects. Therefore, an environmentally sensitive individual may have spent more on local products or products with fully recycled materials and, as a result, generate a higher environmental impact. This is especially true for the clothing and food categories. This limitation affects the accuracy of the calculation of the carbon footprint of environmentally and ethically conscious consumers, whose higher expenses incurred would be penalized by the calculator in question. Further studies should differentiate between more environmentally friendly products and regular products, which would allow researchers to test whether the consumption of environmentally friendly products leads to a significantly lower environmental impact for environmentally concerned consumers.

Fifth, there could be considerable differences between participants' reported and observed behavior. Since the results depend on the use of retrospective information, respondents may not remember their past expenditures very accurately. Because they had to count their expenditures over a certain period, for numerous types of products and services (electricity, food, transportation, etc.), the amount spent could represent only an approximate reconstruction of their actual expenditures. In order to reduce participants' memory bias, the expenditure period was adapted to the type of expenditure (e.g., home energy expenses per month, education expenses per year, dining out expenses per month, etc.). Furthermore, a self-report measure was used to estimate consumption patterns. Such measures are greatly influenced by memory. Future research would profit from measuring real buying behavior.

\subsection{Research Implications}

By examining the environmental impact of anti-consumption lifestyles, environmental concern and ethically minded consumption, this study provides additional empirical evidence that tightwadism is associated with lower carbon footprint, thus confirming existing theories that anti-consumption lifestyles may play a role in achieving more sustainable societies [1,2,19-21]. Few studies have considered various lifestyles in a single framework, as well as explored how emissions impact knowledge moderates the effect of anti-consumption on environmental impact. Our findings demonstrate that emissions impact knowledge increases the negative association between tightwadism and environmental impact. This finding should motivate researchers to investigate additional conditions and personality traits that may further increase one's motivation to reduce consumption. The results of this study also indicate that environmental and ethical concerns fail to generate a positive impact on the environment, thereby reinforcing the "green gap" raised by previous studies. Surprisingly, we found that ethically minded consumption is positively associated with environmental impact. Future research should investigate this finding, as it seems to suggest that one's ethical concerns seems to conflict with other needs and desires, leading to a failure in reducing one's environmental impact. While this research provides a foundation for future studies on anti-consumption lifestyles and their effects on the environment, it also paves the way for taking further measures to create a more sustainable society. Until recently, the ecological modernization approach to consumption and the dominant topic in sustainable development consisted in creating technological or efficiency-driven solution for consumers. While some resources can benefit from these improvements, others can only be 
protected by restricting final consumption. This research reiterates the importance of turning away from traditional material-driven consumption patterns, given that environmental and ethical concerns appear to have a limited effect on environmental impact reduction, toward more anti-consumption-based lifestyles such as tightwadism. We propose that adopting a tightwad lifestyle can substantially reduce annual personal emissions and environmental impact to build a strong foundation for living a sustainable life. In this context, it seems essential to move away from this emphasis on technology and efficiency improvements, which give the delusive promise that environmental protection and materialistic lifestyles can coexist.

Public policy makers and companies concerned with achieving significant progress towards sustainable development have a role to play in this transition to environmentally sustainable consumption. Instead of focusing on environmentally and ethically conscious messages in their practices and campaigns, with much smaller potential emissions reductions, our findings should encourage them to promote and endorse values such as tightwadism, sufficiency, and consumption reduction. Furthermore, our findings suggest that policy makers should enhance knowledge around the impact of consumption reduction on the environment and raise the question of consumption reduction in the public debate to make it acceptable for consumers and gradually integrate it into the dominant consumption ideology. This call for sufficiency is not limited to policy makers, but also to commercial marketers [110].

Author Contributions: L.T. worked on the conceptualization, methodology, data collection, formal analyses, writing of the original manuscript and project administration. M.V.N. worked on the conceptualization, methodology, formal analyses, data curation supervision and writing of the original draft, review and editing of the text. All authors have read and agreed to the published version of the manuscript.

Funding: This research received no external funding.

Conflicts of Interest: The authors declare no conflict of interest.

\section{References}

1. García-de-Frutos, N.; Ortega-Egea, J.M.; Martínez-del-Río, J. Anti-consumption for environmental sustainability: Conceptualization, review, and multilevel research directions. J. Bus. Ethics 2018, 148, 411-435. [CrossRef]

2. Black, I.R.; Cherrier, H. Anti-consumption as part of living a sustainable lifestyle: Daily practices, contextual motivations and subjective values. J. Consum. Behav. 2010, 9, 437-453. [CrossRef]

3. Chatzidakis, A.; Lee, M.S. Anti-consumption as the study of reasons against. J. Macromark. 2013, 33, $190-203$. [CrossRef]

4. Corral-Verdugo, V.; Bechtel, R.B.; Fraijo-Sing, B. Environmental beliefs and water conservation: An empirical study. J. Environ. Psychol. 2003, 23, 247-257. [CrossRef]

5. Howard-Grenville, J.; Buckle, S.J.; Hoskins, B.J.; George, G. Climate change and management. Acad. Manag. J. 2014, 57, 615-623. [CrossRef]

6. Jackson, T. Live better by consuming less? Is there a "double dividend" in sustainable consumption? J. Ind. Ecol. 2005, 9, 19-36. [CrossRef]

7. Peattie, K.; Peattie, S. Social marketing: A pathway to consumption reduction? J. Bus. Res. 2009, 62, 260-268. [CrossRef]

8. Connolly, J.; Prothero, A. Sustainable consumption: Consumption, consumers and the commodity discourse. Consum. Mark. Cult. 2003, 6, 275-291. [CrossRef]

9. Kilbourne, W.E.; Carlson, L. The dominant social paradigm, consumption, and environmental attitudes: Can macromarketing education help? J. Macromark. 2008, 28, 106-121. [CrossRef]

10. Kjellberg, H. Market practices and over-consumption. Consum. Mark. Cult. 2008, 11, 151-167. [CrossRef]

11. Varey, R.J. Marketing means and ends for a sustainable society: A welfare agenda for transformative change. J. Macromark. 2010, 30, 112-126. [CrossRef]

12. Carfora, V.; Catellani, P.; Caso, D.; Conner, M. How to reduce red and processed meat consumption by daily text messages targeting environment or health benefits. J. Environ. Psychol. 2019, 65, 101319. [CrossRef] 
13. Palomo-Vélez, G.; Tybur, J.M.; van Vugt, M. Unsustainable, unhealthy, or disgusting? Comparing different persuasive messages against meat consumption. J. Environ. Psychol. 2018, 58, 63-71. [CrossRef]

14. Taufik, D. Prospective "warm-glow" of reducing meat consumption in China: Emotional associations with intentions for meat consumption curtailment and consumption of meat substitutes. J. Environ. Psychol. 2018, 60, 48-54. [CrossRef]

15. Cowen, L.; Gatersleben, B. Testing for the size heuristic in householders' perceptions of energy consumption. J. Environ. Psychol. 2017, 54, 103-115. [CrossRef]

16. Bamberg, S. Applying the stage model of self-regulated behavioral change in a car use reduction intervention. J. Environ. Psychol. 2013, 33, 68-75. [CrossRef]

17. Chng, S.; Abraham, C.; White, M.P.; Hoffmann, C.; Skippon, S. Psychological theories of car use: An integrative review and conceptual framework. J. Environ. Psychol. 2018, 55, 23-33. [CrossRef]

18. Nayum, A.; Klöckner, C.A. A comprehensive socio-psychological approach to car type choice. J. Environ. Psychol. 2014, 40, 401-411. [CrossRef]

19. Nepomuceno, M.V.; Laroche, M. When materialists intend to resist consumption: The moderating role of self-control and long-term orientation. J. Bus. Ethics. 2017, 143, 467-483. [CrossRef]

20. Kropfeld, M.I.; Nepomuceno, M.V.; Dantas, D.C. The Ecological Impact of Anticonsumption Lifestyles and Environmental Concern. J. Public Policy Mark. 2018, 37, 245-259. [CrossRef]

21. Nasr, N. The beauty and the beast of consumption: A review of the consequences of consumption. J. Consum. Mark. 2019, 36, 911-925. [CrossRef]

22. Lee, M.; Roux, D.; Cherrier, H.; Cova, B. Anti-consumption and consumer resistance: Concepts, concerns, conflicts and convergence. Eur. J. Mark. 2011, 45. [CrossRef]

23. Lee, M.S.; Fernandez, K.V.; Hyman, M.R. Anti-consumption: An overview and research agenda. J. Bus. Res. 2009, 62, 145-147. [CrossRef]

24. Sheth, J.N.; Sethia, N.K.; Srinivas, S. Mindful consumption: A customer-centric approach to sustainability. J. Acad. Mark. Sci. 2011, 39, 21-39. [CrossRef]

25. Mulrow, J.; Machaj, K.; Deanes, J.; Derrible, S. The state of carbon footprint calculators: An evaluation of calculator design and user interaction features. Sustain. Prod. Consum. 2018, 18, 33-40. [CrossRef]

26. Carrigan, M.; Szmigin, I.; Wright, J. Shopping for a better world? An interpretive study of the potential for ethical consumption within the older market. J. Consum. Mark. 2004, 21, 401-417. [CrossRef]

27. Auger, P.; Devinney, T.M. Do what consumers say matter? The misalignment of preferences with unconstrained ethical intentions. J. Bus. Ethics. 2007, 76, 361-383. [CrossRef]

28. Devinney, T.M.; Auger, P.; Eckhardt, G.; Birtchnell, T. The other CSR: Making consumers socially responsible. Stanf. Soc. Innov. Rev. 2006, 30-37. [CrossRef]

29. Fan, Y. Ethical branding and corporate reputation. Corp. Commun. Int. J. 2005, 10, 341-350. [CrossRef]

30. Roberts, J.A. Green consumers in the 1990s: Profile and implications for advertising. J. Bus. Res. 1996, 36, 217-231. [CrossRef]

31. Uusitalo, L. Are environmental attitudes and behaviour inconsistent? Findings from a Finnish study. Scand. Political Stud. 1990, 13, 211-226. [CrossRef]

32. Mostafa, M.M. Shades of green: A psychographic segmentation of the green consumer in Kuwait using self-organizing maps. Expert Syst. Appl. 2009, 36, 11030-11038. [CrossRef]

33. Oğuz, D.; Kavas, S. Environmental awareness of university students in Ankara, Turkey. Afr. J. Agric. Res. 2010, 5, 2629-2636.

34. Suki, N.M. Young consumer ecological behaviour: The effects of environmental knowledge, healthy food, and healthy way of life with the moderation of gender and age. Manag. Environ. Qual. Int. J. 2013, 24, 726-737. [CrossRef]

35. Lastovicka, J.L.; Bettencourt, L.A.; Hughner, R.S.; Kuntze, R.J. Lifestyle of the tight and frugal: Theory and measurement. J. Consum. Res. 1999, 26, 85-98. [CrossRef]

36. Rick, S.I.; Cryder, C.E.; Loewenstein, G. Tightwads and spendthrifts. J. Consum. Res. 2007, 34, 767-782. [CrossRef]

37. Iwata, O. Attitudinal and behavioral correlates of voluntary simplicity lifestyles. Soc. Behav. Personal. Int. J. 1997, 25, 233-240. [CrossRef]

38. Rich, S.A.; Wright, B.J.; Bennett, P.C. Development of the Voluntary Simplicity Engagement Scale: Measuring Low-Consumption Lifestyles. J. Consum. Policy 2019, 43, 1-19. [CrossRef] 
39. Boulstridge, E.; Carrigan, M. Do consumers really care about corporate responsibility? Highlighting the attitude-Behaviour gap. J. Commun. Manag. 2000, 4, 355-368. [CrossRef]

40. Carrigan, M.; Attalla, A. The myth of the ethical consumer-do ethics matter in purchase behaviour? J. Consum. Mark. 2001, 18, 560-578. [CrossRef]

41. Chatzidakis, A.; Hibbert, S.; Smith, A.P. Why people don't take their concerns about fair trade to the supermarket: The role of neutralisation. J. Bus. Ethics. 2007, 74, 89-100. [CrossRef]

42. Carrigan, M.; Moraes, C.; Leek, S. Fostering responsible communities: A community social marketing approach to sustainable living. J. Bus. Ethics 2011, 100, 515-534. [CrossRef]

43. Moraes, C.; Carrigan, M.; Szmigin, I. The coherence of inconsistencies: Attitude-behaviour gaps and new consumption communities. J. Mark. Manag. 2012, 28, 103-128. [CrossRef]

44. Ellen, P.S.; Wiener, J.L.; Cobb-Walgren, C. The role of perceived consumer effectiveness in motivating environmentally conscious behaviors. J. Public Policy Mark. 1991, 10, 102-117. [CrossRef]

45. Wynes, S.; Nicholas, K.A. The climate mitigation gap: Education and government recommendations miss the most effective individual actions. Environ. Res. Lett. 2017, 12, 074024. [CrossRef]

46. Vandermerwe, S.; Oliff, M.D. Customers drive corporations. Long Range Plan. 1990, 23, 10-16. [CrossRef]

47. Worcester, R.M. Public and elite attitudes to environmental issues. Int. J. Public Opin. Res. 1993, 5, 315-334. [CrossRef]

48. Zavestoski, S. The social-psychological bases of anticonsumption attitudes. Psychol. Mark. 2002, 19, $149-165$. [CrossRef]

49. Cherrier, H.; Black, I.R.; Lee, M. Intentional non-consumption for sustainability: Consumer resistance and/or anti-consumption? Eur. J. Mark. 2011, 45, 1757-1767. [CrossRef]

50. Nepomuceno, M.V.; Rohani, M.; Grégoire, Y. Consumer resistance: From anti-consumption to revenge. In Consumer Perception of Product Risks and Benefits; Springer: Cham, Switzerland, 2017.

51. Grégoire, Y.; Fisher, R.J. Customer betrayal and retaliation: When your best customers become your worst enemies. J. Acad. Mark. Sci. 2008, 36, 247-261. [CrossRef]

52. Grégoire, Y.; Laufer, D.; Tripp, M.T. A comprehensive model of customer direct and indirect revenge: Understanding the effects of perceived greed and customer power. J. Acad. Mark. Sci. 2010, 38, 738-758. [CrossRef]

53. Eckhardt, G.M.; Belk, R.; Devinney, T.M. Why don't consumers consume ethically? J. Consum. Behav. 2010, 9, 426-436. [CrossRef]

54. Iyer, R.; Muncy, J.A. Purpose and object of anti-consumption. J. Bus. Res. 2009, 62, 160-168. [CrossRef]

55. Leonard-Barton, D. Voluntary simplicity lifestyles and energy conservation. J. Consum. Res. 1981, 8, $243-252$. [CrossRef]

56. Craig-Lees, M.; Hill, C. Understanding voluntary simplifiers. Psychol. Mark. 2002, 19, 187-210. [CrossRef]

57. Elgin, D. Voluntary Simplicity, 2nd ed.; Harper Collins: New York, NY, USA, 2010.

58. Prelec, D.; Loewenstein, G. The red and the black: Mental accounting of savings and debt. Mark. Sci. 1998, 17, 4-28. [CrossRef]

59. Schor, J.B. The Overspent American: Why We Want What We don't Need; Harper Perennial: New York, NY, USA, 1999.

60. Fujii, S. Environmental concern, attitude toward frugality, and ease of behavior as determinants of pro-environmental behavior intentions. J. Environ. Psychol. 2006, 26, 262-268. [CrossRef]

61. Gärling, T.; Fujii, S.; Gärling, A.; Jakobsson, C. Moderating effects of social value orientation on determinants of proenvironmental behavior intention. J. Environ. Psychol. 2003, 23, 1-9. [CrossRef]

62. Kim, H.S.; Damhorst, M.L. Environmental attitude and commitment in relation to ad message credibility. J. Fash. Mark. Manag. Int. J. 1999, 3, 18-30. [CrossRef]

63. Antil, J.H. Socially responsible consumers: Profile and implications for public policy. J. Macromark. 1984, 4, 18-39. [CrossRef]

64. Bord, R.J.; O'connor, R.E.; Fisher, A. In what sense does the public need to understand global climate change? Public Underst. Sci. 2000, 9, 205-218. [CrossRef]

65. Moisander, J. Motivational complexity of green consumerism. Int. J. Consum. Stud. 2007, 31, 404-409. [CrossRef]

66. Wiener, J.L.; Doescher, T.A. A framework for promoting cooperation. J. Mark. 1991, 55, 38-47. [CrossRef] 
67. Auld, J.W. Consumers, cars and communities: The challenge of sustainability. Int. J. Consum. Stud. 2001, 25, 228-237. [CrossRef]

68. Casimir, G.; Dutilh, C. Sustainability: A gender studies perspective. Int. J. Consum. Stud. 2003, 27, 316-325. [CrossRef]

69. Black, I. Sustainability through anti-consumption. J. Consum. Behav. 2010, 9, 403-411. [CrossRef]

70. Bird, K.; Hughes, D.R. Ethical consumerism: The case of "Fairly-Traded" coffee. Bus. Ethics A Eur. Rev. 1997, 6, 159-167. [CrossRef]

71. Carrigan, M.; Marinova, S.; Szmigin, I.; De Pelsmacker, P.; Janssens, W.; Sterckx, E.; Mielants, C. Consumer preferences for the marketing of ethically labelled coffee. Int. Mark. Rev. 2005, 22, 512-530.

72. Crane, A. Unpacking the ethical product. J. Bus. Ethics. 2001, 30, 361-373. [CrossRef]

73. Strong, C. Features contributing to the growth of ethical consumerism-a preliminary investigation. Mark. Intell. Plan. 1996, 14, 5-13. [CrossRef]

74. Cowe, R.; Williams, S. Who are the Ethical Consumers? Co-Operative Bank/Mori Survey; The Cooperative Bank: Manchester, UK, 2001.

75. Gelb, B.D. More boycotts ahead? Some implications. Bus. Horiz. 1995, 38, 70-77. [CrossRef]

76. Blend, J.R.; Van Ravenswaay, E.O. Measuring consumer demand for ecolabeled apples. Am. J. Agric. Econ. 1999, 81, 1072-1077. [CrossRef]

77. Loureiro, M.L.; McCluskey, J.J.; Mittelhammer, R.C. Will consumers pay a premium for eco-labeled apples? J. Consum. Aff. 2002, 36, 203-219. [CrossRef]

78. Maietta, O.W. The hedonic price of fair trade coffee for the Italian consumer. In Proceedings of the International Conference on Agricultural Policy Reform and the WTO: Where Are We Heading? Capri, Italy, 23-26 June 2003.

79. Trudel, R.; Cotte, J. Does being ethical pay? Wall Str. J. 2008, 12, R1.

80. Billock, T.N. Shifting Consumer Attitudes in the US towards Fair Trade; Fair Trade Resources Network: Philadelphia, PA, USA, 2004; Available online: http://fairtraderesource.org/resources.html (accessed on 19 May 2019).

81. Dawkins, J. The Public's Views of Corporate Responsibility 2003; Ipsos Mori: London, UK, 2004.

82. De Pelsmacker, P.; Driesen, L.; Rayp, G. Do consumers care about ethics? Willingness to pay for fair-trade coffee. J. Consum. Aff. 2005, 39, 363-385. [CrossRef]

83. Doane, D. Taking flight: The rapid growth of ethical consumerism. Lond. New Econ. Found. 2001, 1, 1-15.

84. Transfair U.S.A. Fair Trade Coffee Facts and Figures. 2005. Available online: http://www.transfairusa.org/ content/Downloads/2005Q2FactsandFigures.pdf (accessed on 26 November 2020).

85. Vermeir, I.; Verbeke, W. Sustainable food consumption: Exploring the consumer attitude-behaviour gap. J. Agric. Environ. Ethics 2004, 4, 268.

86. Bray, J.; Johns, N.; Kilburn, D. An exploratory study into the factors impeding ethical consumption. J. Bus. Ethics. 2011, 98, 597-608. [CrossRef]

87. KPMG/Synovate. KPMG and Synovate 'Retailers Are Not Influenced by Ethical Consumers; It's Simply that a Socially Responsible Retailer is More Profitable' Retail Think Tank White. 2007. Available online: http://www.retailthinktank.co.uk/news/news_releases/white_paper_-_july_2007/ (accessed on 26 November 2020).

88. Olli, E.; Grendstad, G.; Wollebaek, D. Correlates of environmental behaviors: Bringing back social context. Environ. Behav. 2001, 33, 181-208. [CrossRef]

89. Lozano, R. Incorporation and institutionalization of SD into universities: Breaking through barriers to change. J. Clean. Prod. 2006, 14, 787-796. [CrossRef]

90. Kaiser, F.G.; Fuhrer, U. Ecological behavior's dependency on different forms of knowledge. Appl. Psychol. 2003, 52, 598-613. [CrossRef]

91. Attari, S.Z.; DeKay, M.L.; Davidson, C.I.; De Bruin, W.B. Public perceptions of energy consumption and savings. Proc. Natl. Acad. Sci. 2010, 107, 16054-16059. [CrossRef] [PubMed]

92. Oppenheimer, D.M.; Meyvis, T.; Davidenko, N. Instructional manipulation checks: Detecting satisficing to increase statistical power. J. Exp. Soc. Psychol. 2009, 45, 867-872. [CrossRef]

93. Iwata, O. An evaluation of consumerism and lifestyle as correlates of a voluntary simplicity lifestyle. Soc. Behav. Personal. Int. J. 2006, 34, 557-568. [CrossRef]

94. Nepomuceno, M.V.; Laroche, M. The impact of materialism and anti-consumption lifestyles on personal debt and account balances. J. Bus. Res. 2015, 68, 654-664. [CrossRef] 
95. Dunlap, R.E.; Van Liere, K.D.; Mertig, A.G.; Jones, R.E. New trends in measuring environmental attitudes: Measuring endorsement of the new ecological paradigm: A revised NEP scale. J. Soc. Issues 2000, 56, 425-442. [CrossRef]

96. Sudbury-Riley, L.; Kohlbacher, F. Ethically minded consumer behavior: Scale review, development, and validation. J. Bus. Res. 2016, 69, 2697-2710. [CrossRef]

97. Carbon Footprint Ltd. Carbon Calculator. 2017. Available online: https://www.carbonfootprint.com/calculator.aspx (accessed on 26 November 2020).

98. Fornell, C.; Larcker, D.F. Evaluating structural equation models with unobservable variables and measurement error. J. Mark. Res. 1981, 18, 39-50. [CrossRef]

99. Hayes, A.F. Introduction to Mediation, Moderation, and Conditional Process Analysis Second Edition: A Regression-Based Approach; The Guilford Press: New York, NY, USA, 2018.

100. Evans, D. Thrifty, green or frugal: Reflections on sustainable consumption in a changing economic climate. Geoforum 2011, 42, 550-557. [CrossRef]

101. Kollmuss, A.; Agyeman, J. Mind the gap: Why do people act environmentally and what are the barriers to pro-environmental behavior? Environ. Educ. Res. 2002, 8, 239-260. [CrossRef]

102. Kim, B.; Schuldt, J.P. Judging the environmental impact of green consumption: Evidence of quantity insensitivity. J. Environ. Psychol. 2018, 60, 122-127. [CrossRef]

103. Mobley, C.; Vagias, W.M.; DeWard, S.L. Exploring additional determinants of environmentally responsible behavior: The influence of environmental literature and environmental attitudes. Environ. Behav. 2010, 42, 420-447. [CrossRef]

104. Randall, D.M.; Fernandes, M.F. The social desirability response bias in ethics research. J. Bus. Ethics. 1991, 10, 805-817. [CrossRef]

105. Gossen, M.; Ziesemer, F.; Schrader, U. Why and how commercial marketing should promote sufficient consumption: A systematic literature review. J. Macromark. 2019, 39, 252-269. [CrossRef]

106. Statista. Educational Attainment Distribution in the United States from 1960 to 2019. 2020. Available online: https://www.statista.com/statistics/184260/educational-attainment-in-the-us/ (accessed on 26 November 2020).

107. Statista. Total Population in the United States by Gender from 2010 to 2025. 2020. Available online: https://www.statista.com/statistics/737923/us-population-by-gender/ (accessed on 26 November 2020).

108. Statista. Median Age of the Resident Population of the United States from 1960 to 2019. 2020. Available online: https://www.statista.com/statistics/241494/median-age-of-the-us-population/ (accessed on 26 November 2020).

109. Statista. Marital Status of the U.S. Population in 2019, by Sex. 2020. Available online: https://www.statista. com/statistics/242030/marital-status-of-the-us-population-by-sex/ (accessed on 26 November 2020).

110. Statista. Percentage Distribution of Household Income in the U.S. in 2019. 2020. Available online: https://www.statista.com/statistics/203183/percentage-distribution-of-household-income-in-the-us/ (accessed on 26 November 2020).

Publisher's Note: MDPI stays neutral with regard to jurisdictional claims in published maps and institutional affiliations.

(C) 2020 by the authors. Licensee MDPI, Basel, Switzerland. This article is an open access article distributed under the terms and conditions of the Creative Commons Attribution (CC BY) license (http://creativecommons.org/licenses/by/4.0/). 